\title{
Kamica moczowa - historia naturalna i leczenie
}

Dr n. med. AdAM Kwinta

Szpital Zakonu Bonifratrów św. Jana Grandego w Krakowie Polskie Towarzystwo Urologiczne

Złogi nerkowe można badać takimi samymi metodami, jakimi bada się skały. Pozwala to uzyskać informacje o przyczynach ich powstawania i dobrać skuteczne leczenie.

Każdy, kto przeżył atak kolki nerkowej, długo tego nie zapomni. A takich osób jest wiele. Kamica nerkowa jest bowiem jedną z najbardziej rozpowszechnionych chorób układu moczowego. Towarzyszy człowiekowi od zarania dziejów. Badania archeologiczne wykazały obecność złogów kamieni u mumii egipskich pochodzących z około 5000 lat p.n.e. ${ }^{1}$

Kamień nerkowy (lub kamienie) w początkowej fazie może nie dawać żadnych objawów, chory przez lata może nie wiedzieć, że w jego układzie moczowym dzieje się coś złego. Kiedy jednak kamień zacznie się przemieszczać, wtedy bolesne symptomy choroby skłaniają do poszukiwania natychmiastowej pomocy lekarza. W pierwszej kolejności musimy zabezpieczyć chorego lekami przeciwbólowymi i wykonać odpowiednią diagnostykę w celu ustalenia planu leczenia. $\mathrm{Na}$ diagnostykę składają się: badanie podmioto-

${ }^{1}$ J. Leńko, Kamica moczowa, Warszawa 1976, s. 129-141. 
we i przedmiotowe, USG jamy brzusznej, RTG przeglądowe jamy brzusznej, urografia infuzyjna, analiza moczu i posiew moczu, ocena parametrów nerkowych takich jak poziom kreatyniny, mocznika, elektrolitów. USG stanowi przełom w porównaniu do dawnych metod, gdyż jest to badanie nieinwazyjne, szybkie i powtarzalne ${ }^{2}$.

Kamicę można leczyć farmakologicznie, dążąc do „wypłukania” kamienia z układu moczowego. Jeśli jednak kamień jest duży lub zablokował odpływ moczu, pojawia się gorączka, a mocz przyjmuje czerwoną barwę, co świadczy o krwawieniu - wówczas interwencja urologiczna jest niezbędna. Obecnie rzadko zachodzi konieczność wykonania operacji chirurgicznej w celu usunięcia kamienia lub kamieni moczowych. Stosujemy inne, nowoczesne i mniej inwazyjne metody ${ }^{3}$.

URSL - ureterorenoskopia (litotrypsja ureterorenoskopowa) polega na usunięciu złogu lub złogów z moczowodu przez cewkę moczową. Zabieg wykonuje się w znieczuleniu zewnątrzoponowym bez konieczności jakiegokolwiek nacinania tkanek. Urolog wprowadza ureterorenoskop przez cewkę moczową do pęcherza moczowego, a następnie do moczowodu. Przyrząd wyposażony jest w układ optyczny i kamerę (co pozwala na obserwowanie całego zabiegu na ekranie monitora) oraz kanał roboczy wykorzystywany do wprowadzenia narzędzi endoskopowych. Kamień można usunąć w całości lub wcześniej rozdrobnić go na mniejsze

2 J. Zieliński, J. Leńko, Urologia, Warszawa 1992.

${ }^{3}$ A. Borkowski, A. Borówka, Nowe metody leczenia kamicy górnych dróg moczowych, Warszawa 1994, s. 41-196. 
fragmenty. Zabieg, w zależności od wielkości i lokalizacji kamienia, może trwać od kilku minut do godziny.

Inne metody leczenia kamicy to litotrypsja pozaustrojowa (ESWL) i nefrolitotrypsja przezskórna (PCNL). Litotrypsja pozaustrojowa to rozbijanie kamienia moczowego wewnątrz organizmu pacjenta przy użyciu tzw. fali wstrząsowej. Kamień ulega rozbiciu na cząstki wielkości ziaren piasku, które łatwo są wydalane z moczem. Zabieg zwykle przeprowadza się ambulatoryjnie i nie wymaga on znieczulenia.

Nefrolitotrypsja przezskórna zwykle jest wykonywana, gdy kamień moczowy w nerce jest duży lub położony w takim miejscu, że nie może być rozbity przy użyciu litotrypsji. Zabieg wykonuje się w znieczuleniu. Polega on na wprowadzeniu przez niewielkie nacięcie skóry w okolicy nerki do miedniczki nerkowej instrumentu zwanego nefroskopem, przez który urolog może obejrzeć kamień moczowy, dokładnie określić jego położenie i odpowiednimi narzędziami rozdrobnić go na mniejsze kawałki, które następnie usuwa.

Aby zrozumieć współczesne metody, musimy spojrzeć wstecz - jak dawniej odbywało się usuwanie kamieni moczowych. Opis naocznego świadka takiej procedury zawiera książka Jürgena Thorwalda Stulecie chirurgów:

Indie 1854 r. Mukerji, „wycinacz kamieni z Khanpur”, operował dziecko z powodu kamieni pęcherzowych, choroby występującej wówczas we wszystkich częściach świata już w młodocianym wieku.

Członki chłopca prężyły się w żelaznym uchwycie rąk półnagiego pomocnika. Mukerji wyciągnął naoliwione palce, którymi przez odbytnicę docisnął kamień do dna pęcherza. Głęboko w kroczu dziecka tkwił nóż czerwony od try- 
skającej krwi. Wbił go szybkim ruchem przez odbyt między mosznę i krocze aż do pęcherza.

Gdy go wyciągnął, chłopiec miotał głową w dzikim bólu, a z jego gardła wydobywał się głośny, rozdzierający serce krzyk. Mukerji wsadził wskazujący palec w ranę i starał się wymacać kamień.

Potem pomagał sobie żelaznymi kleszczami, leżącymi na lepkiej od brudu podłodze. Po usunięciu kamienia nie troszczył się o krwawiąca ranę, nie próbował zatamować krwi. Dał znać pomocnikowi, który ścisnął uda jęczącego chłopca konopnymi sznurami ${ }^{4}$.

Usuwanie kamienia wykonywano przez krocze, bowiem bano się otworzyć pęcherz moczowy cięciem w podbrzuszu, ze względu na możliwość uszkodzenia otrzewnej i jelit. Zabieg ten, określany jako sectio alta, zaczęto wykonywać z powodzeniem w drugiej połowie XIX wieku. W Krakowie pierwszą operację nerki z powodu kamicy wykonał Alfred Obaliński w 1895 roku. Historia leczenia operacyjnego złogów to okres życia trzech pokoleń ${ }^{5}$.

Metod leczenia kamicy jest kilka. Każda z nich ma za zadanie usunięcie złogów z układu moczowego i powstrzymanie postępu choroby. Pomimo to często obserwuje się nawrót kamicy. Bo kamień jest tylko skutkiem procesów chorobowych toczących się w organizmie. Usuwając złogi, nie zawsze usuwamy przyczyny ich powstawania. Dlatego warto dokładnie przyjrzeć się kamieniom nerkowym. Zawarta jest w nich informacja o przebiegu choroby, można też spre-

\footnotetext{
${ }^{4}$ J. Thorwald, Stulecie chirurgów, Kraków-Wrocław 1987.

${ }^{5}$ E. Michałowski, Urologia operacyjna, Warszawa 1954.
} 
cyzować, dlaczego powstają, co pozwoli dobrać najbardziej odpowiedni kierunek terapii.

Kamienie nerkowe można badać takimi samymi metodami, jakimi bada się skały. Mineralogia, czyli nauka badająca budowę i procesy powstawania minerałów, może więc służyć medycynie. Co więcej, analiza biomineralogiczna kamieni nerkowych powinna być badaniem rutynowym ${ }^{6}$.

Kamienie (złogi) powstają w nerkach lub drogach moczowych na skutek wytrącania się związków chemicznych stanowiących prawidłowe lub patologiczne składniki obecne w moczu. Dlaczego do tego dochodzi? Odpowiedź nie jest prosta, bowiem przyczyn może być wiele. Kamica nerkowa może występować w jednej rodzinie i wówczas mówimy o genetyce. Przyczyną kamicy może być również utrudniony odpływ moczu (np. z powodu zwężenia moczowodu, przerostu prostaty), przewlekłe infekcje w drogach moczowych, zarówno bakteryjne, jak i grzybicze, a także inne choroby, np. nadczynność przytarczyc, osteoporoza, choroba Leśniowskiego-Crohna, operacje jelita cienkiego. Kamicy sprzyja przyjmowanie zbyt dużych dawek witaminy D lub preparatów wapnia, a także bardzo duże dawki witaminy C. Ryzyko kamicy wzrasta przy nadużywaniu soli, piciu małej ilości płynów, zwłaszcza przy wysokiej temperaturze otoczenia, ciężkiej pracy fizycznej, w gorączce. Niemniej u większości chorych, pomimo prawidłowego wykonania wielu badań diagnostycznych, nie udaje się potwierdzić bezpośredniej przyczyny tworzenia się kamieni moczowych.

${ }^{6}$ M. Pawlikowski, Kryształy w organizmie człowieka, Kraków 1993, s. 82-89; M. Pawlikowski, Biomineralogia kamieni nerkowych i żółciowych, Kraków 2016. 
Kamienie nerkowe mają różną wielkość, kształty i skład chemiczny. Część z nich jest krucha, łatwa do rozpuszczenia, część posiada twardą i zwartą krystaliczną strukturę. Kamienie mogą być okrągłe, gładkie, zlepione razem lub o ostrych zarysach i kształtach. Najogólniej dzielą się na fosforany, szczawiany i moczany oraz złogi mieszane, np. fosforanowo-szczawianowe. Także inne związki chemiczne mogą krystalizować w nerkach i tworzyć kamienie, jednak występują one rzadziej

Na podstawie badań mineralogicznych można dokładnie określić skład mineralny i chemiczny kamieni, a następnie zrekonstruować proces ich powstawania lub rozpuszczania. Ustalenie sposobu powstania złogów u danego pacjenta pomaga odkryć, jakie zmiany w organizmie doprowadziły do choroby. A o tym, że jest to zjawisko skomplikowane, świadczy znaczna złożoność struktur kamieni.

Krystalizacja kamienia zawsze jest wynikiem przekroczenia tzw. iloczynu rozpuszczalności, czyli przesycenia moczu tak dużą (nadmierną) ilością danego składnika, że musi się on wytrącić w formie osadu. Przyczyną tej sytuacji mogą być nieprawidłowo funkcjonujące nerki (co powoduje nadmierną koncentrację moczu), nerki zainfekowane (kolonie bakteryjne bardzo dobrze widać wówczas podczas badania kamieni), ale także różne zjawiska biochemiczne zachodzące poza nerkami - nerki funkcjonują wówczas normalnie, jednak $\mathrm{z}$ filtrowanej krwi przenika do moczu nadmiar pierwiastków ${ }^{8}$.

${ }^{7}$ W. Różański i in., Składniki morfotyczne kamieni moczowych - kryształy, „Urologia Polska” 1 (2003), s. 11-16.

${ }^{8}$ M. Pawlikowski, A. Kwinta, Kamica moczowa jako ciagty proces krystalizacji i rozpadu kryształów w świetle badań mineralogicznych, „Urologia Polska" 4 (2006). 
Zmianę składu chemicznego moczu powodują zaburzenia pracy któregoś z organów, a budowa i skład mineralny kamieni nerkowych są odzwierciedleniem tych zaburzeń. W ten sposób powstają np. kamienie, w których skład wchodzi wapń. Jeżeli gospodarka wapniem jest zaburzona, organizm nadmiernie go wydala, np. z powodu osteoporozy w moczu powstaje zbyt wysokie stężenie tego pierwiastka, dochodzi do wytrącenia się osadu i formowania się kamieni szczawianowych. Prawdopodobnie także pozanerkowe infekcje organizmu mogą skutkować tworzeniem się kamieni nerkowych. Zlikwidowanie infekcji likwiduje przyczynę nadmiernej mineralizacji krwi, a pośrednio także moczu (fot. 1).

Kamień może utworzyć się np. po infekcji, kiedy organizm wraca do zdrowia i zrzuca wszystkie toksyny, które powstały podczas choroby. Bywa, że kamienie tworzą się u dzieci, które intensywnie ćwiczą, nie uzupełniając utraconej podczas treningów wody, albo - z tych samych powodów - u osób podróżujących często w gorące strefy klimatyczne.

Kamienie powstają także z powodu zbyt dużej koncentracji kwasu moczowego w organizmie. Przyczyny tego nadmiaru są jednak często trudne do ustalenia. Gdy jest to np. wynik nieprawidłowego funkcjonowania nerek, oprócz kamieni nerkowych mogą powstawać zjawiska sprzyjające rozwojowi dny moczanowej z odczynem stawowym i zaburzeń centrów układu nerwowego, w tym także mózgu.

Poszczególne warstwy kamieni nerkowych zbudowane są najczęściej z różnych minerałów. Odzwierciedla to odmienne stany chemizmu moczu, a więc różne stany chemizmu krwi. Wiedząc, z jakich minerałów tworzy się kamień i co organizm odrzuca, można doszukiwać się, skąd te 


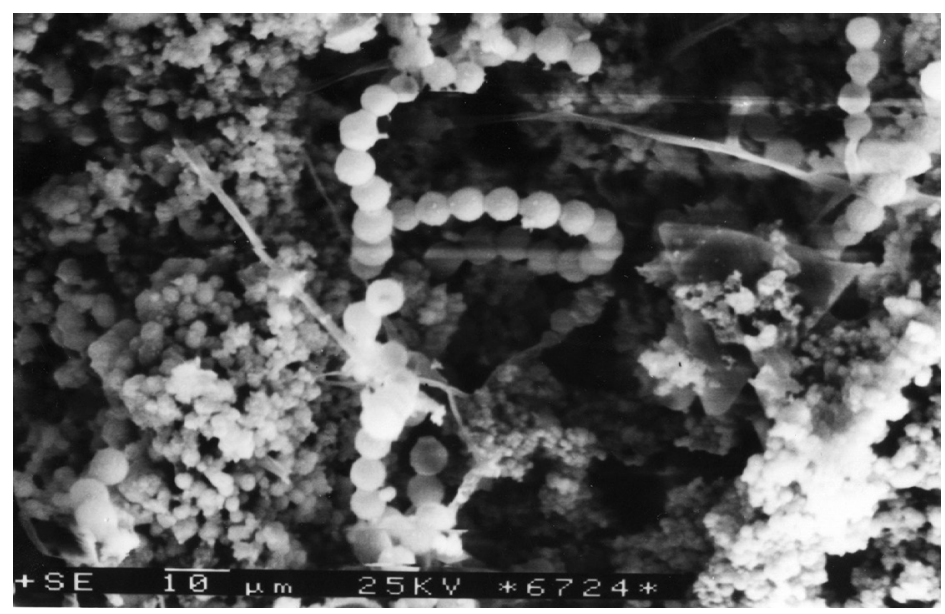

Fot. 1. Bakterie widoczne w centrum kamienia nerkowego początek krystalizacji. Mikroskop elektronowy

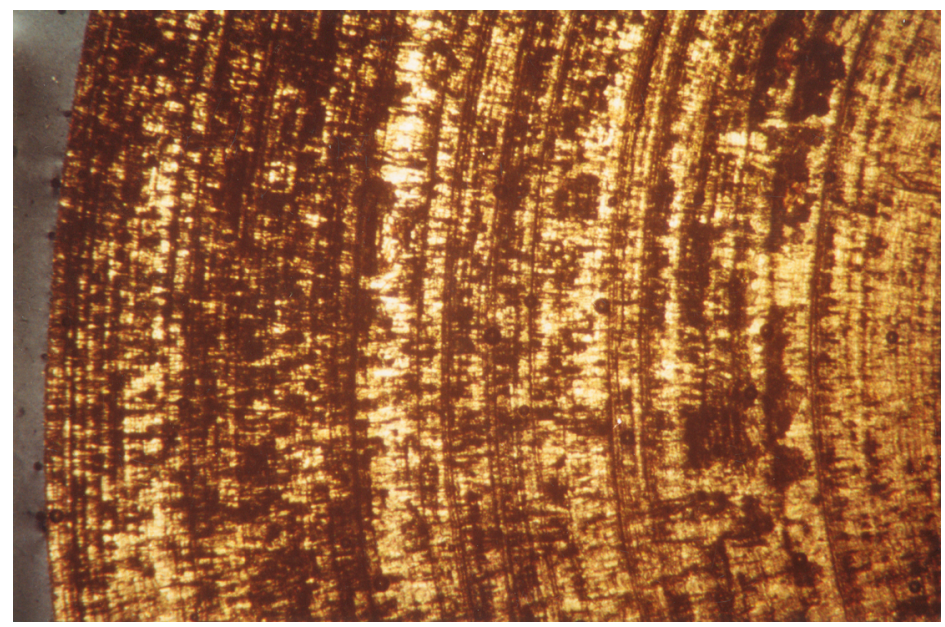

Fot. 2. Widoczna typowa warstwowa budowa kamienia nerkowego. W okresach infekcji przeważają fosforany 
składniki złogów są wyprowadzane. Podczas badania mineralogicznego widać, że kamień albo rośnie i zatrzymuje się w procesie wzrostu, albo też rośnie bez przerwy. Niekiedy widać na nim ślady rozpuszczania lub mechaniczne ubytki, pojawiają się naprzemiennie warstwy fosforanowe i szczawianowe lub inne (fot. 2).

Te informacje są istotne dla wyboru dalszej diagnostyki, czy np. zbadać tarczycę i przytarczyce, poziom witaminy D, ustalić, czy hormony są w porządku, czy trzustka działa poprawnie, czy rozwija się jakiś stan zapalny, infekcja itd. Tych przyczyn jest ograniczona liczba, ale jest ich jednak wiele. Poza tym mogą występować w kombinacjach, gdy nie działa jeden czynnik, ale kilka współwystępujących.

Badania kamieni nerkowych z zastosowaniem nowoczesnych, skomplikowanych metod, którymi dysponuje obecnie mineralogia, prowadzi prof. dr hab. Maciej Pawlikowski z Akademii Górniczo-Hutniczej w Krakowie. Z jednej strony wyniki badań mineralogicznych kamieni, z drugiej - wyniki badań diagnostycznych i laboratoryjnych wykonanych u pacjenta pozwalają na dobranie najbardziej optymalnej i skutecznej metody leczenia kamicy nerkowej.

W profilaktyce kamicy moczowej uznane miejsce od lat ma krenoterapia - czyli terapia wodami mineralnych, a także odpowiednia dieta, ziołolecznictwo i leczenie sanatoryjne.

Zamieszczone zdjęcia kamieni nerkowych pochodzą z materiałów prof. dr. hab. Macieja Pawlikowskiego - Pracownia Biomineralogii AGH.

Modlitwa - Zdrowie - Komunikacja Praca i życie sióstr felicjanek red. ks. Robert Nęcek, ks. Wojciech Misztal, Kraków 2019, s. 95-103 DOI: http.doi.org/10.15633/9788374387651.06 
